\title{
The Enterprise and Its Relationship with the Financial System in View of the Innovative Methods of Capitalization: A Literature Review
}

\author{
Maria Fedele ${ }^{1}$ \\ ${ }^{1}$ Department of Business and Law, University of Cassino and Southern Lazio, Italy \\ Correspondence: Maria Fedele, Department of Business and Law, University of Cassino and Southern Lazio, \\ Italy. E-mail: m.fedelecam@libero.it
}

Received: February 24, 2015

Accepted: March 11, 2015

Online Published: April 25, 2015

doi:10.5539/ibr.v8n5p146

URL: http://dx.doi.org/10.5539/ibr.v8n5p146

\begin{abstract}
This paper aims to provide a further contribution to the evolution of the relationship between the system "enterprise" and its over-financial, superordinate level $(\mathrm{L}+1)$ system, in view of the risk-return ratio and taking into account the innovative methods of capitalization of the enterprises. To reach this goal, an inductive methodology has been applied with a focus on literature review. The originality of this paper lies in addressing the issue from a managerial point of view, providing in this way a further contribution. However, the empirical validation of the conceptual model proposed affects the work, thus it lays the basis for future investigations through a quantitative analysis of the bank-enterprise relationship from the view point of enterprise itself, according to the innovative regulation issued by the Basel Committee.
\end{abstract}

Keywords: enterprise, viable system, financial system, financial requirements, equity, relevance of the financial function, funding sources, intersystemic relationships

\section{Introduction}

It is well known that a strong relationship between banks and enterprises produces benefits for both parties. This happened especially in the last years; in order to ensure the stability of the system, the evolution of the rules of banking supervision has defined highly selective criteria for credit access in the form of a credit rating which, in many cases, cannot grant the credit designed to support the strategic choices of the enterprises. This criticality is particularly clear in small enterprises that mainly suffer an "endemically" exposition to bank financing. Based on this issue, the work aims to analyze the development trends of the reference literature about the bank-enterprise relationship and its evolution linked to innovative methods of capitalization. The article is structured as follows: after the introduction, the concept of enterprise is examined in depth, as a complex of interrelated components, both material and non-material, intertwined and in constant communication in order to pursue a common goal. In the third section the author has tried to read the Italian financial system with a systemic approach. Then, the paper will examine the financial needs of the enterprises for the purpose of a proper capital "government". Paragraph five will highlight the role of the financial function in the enterprises that, evolving over time towards a model of strategic finance, interacts with other areas of the management every time when, during the life of the enterprise, objectives and strategies must be defined. The sixth section focuses on funding sources and the need to trigger an inter-systemic relationship between banks and enterprises. The last section focuses on the order of the choice among the different funding sources according to the Pecking Order Theory. The work ends with conclusions, managerial implications and suggestions for the future research.

\section{Enterprise as a Viable System}

In the context of a systemic thinking, the entrepreneurial entity is also called "system" if we refer to a set of interrelated components, both material and non-material, intertwined and in constant communication in order to pursue a common goal. In his Studies, Zappa had already highlighted that "The enterprise, being an economically coordinated unit, is something more than the sum of its components; the complex has some properties not owned by its elements and those elements, on the other hand, do not define it; nor can the characteristics of the complex be given by a mere composition of the characteristics of the components" (Zappa, 1937). Zappa continues: "The company is not a dissociated mass, nor a gathering one, nor a combination of temporary factors and disjointed phenomena ... On the contrary, the company is a working reality: it grows day by day, it is construction is a continuous process, its structures always get renewed and always get fulfilled; in the dynamic processes carried out, 
it always changes and openly reveals itself as required by the changing circumstances which the company itself is obliged to adapt to" (Zappa, 1956).

As a result, the enterprise seen as a system must be observed beyond a particularistic, analytical-mechanistic, reductionist vision of the reality, but in a holistic perspective, by analyzing the phenomena in their entirety, by studying they bonds, their interactions between the elements that build a socio-economic phenomenon, as well as the interactions between phenomena themselves.

The evolution of this idea leads to define the enterprise as a viable system, considered as a category of the genus of the viable systems developed by Stafford Beer, one of the most influential scholars in the field of cybernetic theory applied to managerial sciences.

According to this conceptualization, the enterprise is able to self-regulate in the case situations of internal imbalance and / or pressures coming from the external environment arise (Beer, 1973).

These entities, in fact, can compete and survive in a particular context, if they engage in a continuous dynamic adaptation, transformation, restructuring, and "re-thinking of the business" process (Golinelli, 2000; Barile, 2008a). They have a main and independent ability to generate value, and tend to project expectations in a subjective way, because they strive for their own survival in the reference territorial background (Barile \& Golinelli, 2008; Barile, 2011).

The theoretical construct that allows an effective, overall comprehension of the role of the multiple systemic entities (enterprises, social organizations, individuals, authorities and institutions) that fill the context is the Viable System Approach.

This paradigm perceives the system "enterprise" as a dynamic entity in constant change, characterized by the presence of the governing body that belongs "to the decisional area" and determines the corporate strategies, and by the operational structure belonging to the "the action area" that defines the management decisions and operational processes.

This systemic theory is useful to understand all decision-making processes of organizations and individuals, by proposing a new behavioral approach to business and to the relational interactions in the context. This theory perceives the enterprise as an open system, plunged in an environment filled by other viable systems with which it interacts and exchanges information, materials and energy, as it has been conceptualized by von Bertalanffy in General Systems Theory in 1956. The establishment of this theory in fact, has stimulated studies and applications that have finally considered the company as an open, aimed, probabilistic, complex system, able to self-regulate and to adapt to the environment dynamics; the system could even influence the environment so to achieve its goals more easily and more conveniently: survival, growth and profitability (Beer, 1969; von Bertalanffy, 1971).

The systemic approach has defined the viable system as "a system that survives, stays united and is integral; it is homeostatically balanced both internally and externally and has mechanisms and opportunities to grow, learn and adapt; its aim is to become increasingly effective in its environment" (Beer, 1991).

The viability of the systemic dynamics arises from the relationships and interactions established between the internal components of the structure and between these components again and those of some physical structures belonging to other systems that fill the environment, with the aim to learn and to adapt itself in order to grant survival and development. The context consists of a set of supra-systems the company interacts with; it is the result of the engagement of its governing body which, on the basis of its conceptual and cognitive models, defines the overall scenario surrounding the company.

Within this approach, a central role is played by top government, which must be able to perceive the strong signals and especially the weak ones coming from the supra-systems, in addition to the activation of a process tending to systemic resonance as well as the integration of the strategic resources that make the system "enterprise" survive (Esposito De Falco, 2003).

The VSA asserts that the survival and development of an organization mainly depends on the ability of the governing body to create value for the system itself and its stakeholders through harmonization, and by developing resonance in the interaction.

Thus it is clear the importance of a correct perception, rational reading and effective interpretation of the reference context: this enables to prepare paths of development, compliant with the pressures and expectations projected by the relevant supra-systems, aiming to make the viable system survive and develop. In this way, the governing body can select counterparties and the instruments to continue the process of developing, defining, if necessary, appropriate priorities (Nelson \& Winter, 1982). 
The importance of exogenous entities can be categorized by mean of the "influence" it is able to exercise, because of the constraints (resulting from the "regulation" task of relevant and / or influential entities) or rules (arising from the "self-regulation" activity promoted by the government), taxes, and the "criticality" of the resource assigned to the system "enterprise".

The "influence" exercised or exercisable by the systems is characterized by:

- Contractual power, representative of a set of constraints, more or less relevant, concerning both the definition of the conditions of survival and the definition of performance of the company;

- Ability to establish rules;

- Quality and quantity of penalties related to the non-compliance of constraints and rules.

The features that make a resource "critical" are:

- Number of possible alternatives for its acquirement;

- Average unit cost per acquirement;

- Proportional weight percentage of the volume of the purchased resources of a given type in a given time lapse on the total volume of resources acquired in the same period;

- Probability of losses in the case of out-of-stock;

- Criticality of the process in which the resource is used.

In relation to this, the government rules the nature, establishing stable or occasional relationships, and the degree of openness of the company that allows it to co-evolve with the reference environment, to enhance its business model and to improve its competitive positions achieved, in view of the ability to generate increasing value over time (Golinelli \& Gatti, 2005). This degree of openness varies in time and space, according to a volitional act of this authority and its ability to read the single supra-systems, evaluated by the criticality entailed while pursuing the systemic goals.

Within the conceptual paradigm of viable systems, characterized by an open, flexible structure, with frequent and unlimited flows of internal and external communication, and decision procedures based on consensus and interaction, those relationships between parties and events that generate these interrelationships gain importance, thus harmonizing the reductionist approach of the phenomena and the holistic vision of synthesis (Tagliagambe \& Usai, 1999).

When activating these relationships, it is essential to take into account not only the physical constraints associated with the characteristics of the internal components, but also the rules of conduct arising from the procedures and criteria imposed by reference supra- systems, while implementing consistent system's development paths and, if possible, also resonant with the context.

Consonance can be conceived either from an internal or an external perspective. The internal one, among the components constituting the system, concerns the possibility to share resources in the business processes, in order to achieve a common goal if a structural compatibility between the components exists. The external one, with the supra-systems, comes from the structural adequacy of the territorial offer with the expectations and needs of stakeholders. Thus, it ensures a shared understanding of the context, being this a prerequisite for the fulfillment of the relational synergies.

The consonance is the necessary attitude to seek and achieve social legitimacy and it is a must stop for the enterprise to support its central, representative role that, over time, made it a basic institution of the economic, social and scientific progress.

The achievement of high degrees of resonance, both inside and outside the system "enterprise", is the expression of the systemic effectiveness and the requirement needed to live and survive (Golinelli, 2000).

"If an enterprise pursues and achieves the resonance with the over-financial system, this results in conditions of consonance, and in some cases, resonance, with the individual bank sub-systems. In fact, having consonance and, where possible, a certain resonance with the supra-system, means having adapted the own structure and behavior to the needs, motivations, expectations and objectives of the supra-system and therefore this reflects the needs that the supra-system (the financial one) expresses through the components involved in the relation with the outside (in this case the banks)".

\section{The Italian Financial System Read with a Systemic Approach}

The interpretation of the various superordinate entities that fill the environment contributes significantly to the 
viable system approach. Thus, this makes easier to identify the context seen as a "system of systems" and filled by different socio-economic realities. It can be easily understood as a complex of several complex interacting entities, where "any occurrences affected by the intentional and aware action of each component and where the evolution of each component depends, more or less significantly, on the action of any other part" (Golinelli, 2009).

This includes institutions, enterprises, markets acting as creditors by managing the financial flows between the units in surplus and deficit units in financial resources, institutions and regulatory, supervision and control bodies, bringing to light the financial system that can be properly regarded as a viable, $L+1$ system, as compared to the system "enterprise" of L-order (Forestieri \& Mottura, 1998).

In Italy, the Bank of Italy is responsible for the governing function of the financial system (decisional area); it guides the implementation of the decisions taken by the governing body of the Euro area, regulates and supervises the operational structure and in particular the components - markets and intermediaries. This role aims to ensure monetary and financial stability at a systemic level, that is, the essential requirements for a sustainable development of the economy. The stability arises from the need to protect the units in surplus and to regulate the functioning of the payment system; this task is carried out jointly with the European governing body (ECB).

Being the body responsible for the protection of competition, the Bank of Italy monitors the market conduct of the financial institutions in order to ascertain situations and / or behaviors that occur and that potentially or effectively could damage the competition (Formisano, 2002).

In this context, the bank bases its core business on the implementation of adequate tools with the aim to reconcile the demands of investment of the units in surplus and those in deficit, thus eliminating the barriers that hinder the direct transfer. This activity manages the complex of the contracts between entities, in which respect it acts as the counterparty. Such a process takes place through interventions on the transit funds expressed in terms of volume, maturity transformation and methods for determining rates, while budgeting the differences (Birindelli, et al., 2010). The banks offer the depositor the opportunity to exploit a credit risk that is lower than the one the borrower grants them and that they can manage thanks to their degree of specialization and the number and variety of operations carried out (Formisano, 2002).

Using different forms, in fact, they transfer, manage and monitor the risk that flows from the financial assets produced.

Even the financial system, like any other business enterprise, aims to survive by pursuing efficiency conditions and protecting itself from instability through prevention and contrasting actions (Fabozzi \& Modigliani, 1995). Towards enterprises it exerts "ex ante" expectations and pressures, and a monitoring activity for the activation of co-evolutionary synergistic processes "ex post".

Similarly to the system "enterprise" it consists of a governing body and of an operational structure.

The governing body is composed by many institutions and organizations of international, European and national level, responsible to guide, control and coordinate the system.

Internationally, this function is performed by the Financial Stability Board (FSB), the Basel Committee of central banks, the World Supervisory Authority for Financial Markets (IOSCO), the World Bank (WB) and the International Monetary Fund (IMF).

At EU level there are the European Central Bank (ECB), the European System of Central Banks (ESCB), the European Committee of Banking Supervisors (CEBS), the Committee of European Supervisory Bodies of Listed Companies (CESR), the Committee of the European Supervisory Authority insurance and occupational and company pensions (CEIOPS).

At national level it consists of the Bank of Italy (BDI), ISVAP, Consob, the Authority for Competition and Market (AGCM or Antitrust).

The operational structure, extremely variegated, includes:

- Traditional financial intermediaries (Onado, 2004), such as banks, insurance companies, mutual funds, asset management companies, factoring companies, leasing, consumer credit, venture capital, etc.;

- Brokers operating on regulated financial markets;

- Financial operators operating as financial intermediaries and on the financial markets;

- The so-called "informational" and not financial operators, such as rating agencies, auditing firms, etc., which play a complementary role although necessary for the conduct of trade flows.

Savers and businesses are directly related to the financial system. The first ones provide financial resources in 
surplus with the intention to enhance them among that entity; businesses are units in potential deficit, and they interact in order to meet their needs of acquiring financial resources critical to survive and develop.

The different territorial connotation of the entities composing the financial system, helps enhancing the complexity that qualifies both the governing body and the operating structure.

The systemic-viable qualification and the highlighting of inter-systemic relationships allow the identification of the "bridges" that convey the relationships between units in surplus and those in financial deficit.

The relationship between the financial system and the business system is based on the risk-return relation that is a consequence of the general principle of affordability and risk aversion of the creditors. The risk is associated with the volatility of operating results and the possibility of financial distress of the company financed.

The quality of this relation is based on:

- Efficiency, expressed in terms of time, cost and variety of products that the financial system is able to deliver, which affects the competitive ability and thus the achievement of a durable competitive advantage by the company, with consequences on the general socio-economic system (Myers \& Majluf, 1984);

- The need for stability of the financial system, which implies the protection of fiduciary conditions at the basis of the financial exchanges (Mottura, 1996);

- The institutionalization of the financial system which is entrusted with the function of supporting the growth and economic development of the community, through proper allocation of financial resources (Forestieri, 1993).

The financial system is important for the business entity since it holds a critical resource, irreplaceable and propulsive for all types of business enterprises, and it is able to influence the relationship over time taking advantage of the complex technical-specialist nature of the knowledge, the language used in the financial sector and the possibility to unilaterally renegotiate the terms of the relationship at any time.

Therefore, the need to pursue high levels of consonance in the relationship between the two systems related arises, so as to ensure the survival of the two entities.

\section{The Financial Needs of the Enterprises for the Purpose of a Proper "Capital" Government}

The financial requirement originates from the need to have adequate monetary resources, both quantitative and qualitative, aimed to implement the corporate strategies. It is an expression of the set of investments in fixed and working capital, the return on the capital employed and its repayment and the return on risk capital. This entity is highly dynamic over time due to endogenous factors arisen from the company's life cycle, the current management, the size of the production capacity, the focus on innovation and internationalization, as well as from external factors such as the dynamics of prices, market characteristics, etc. (Giannessi, 1982).

The competitive strategies are relevant to determine the financial profile of the company. Especially during periods of strategic discontinuity, the more the conduct of the company differs from the conduct of its competitors, the more the actions taken to support the critical success factors may change the financial requirements of the company, compared to the characteristics of the sector and the quality of the actual position. The strategic choices implemented may temporarily increase the capital intensity and lower profit margins. This situation is the result of the actions undertaken by the government regarding increases in the rate of development, external growth processes, investment in intangible assets, programs of vertical integration, diversification, internationalization, etc. (Paravani \&Tagliavini, 2006).

For the purpose of a proper government of the capital, it is appropriate to quantify the extent of the financial requirements, taking into account the business life cycle (Weston, Brigham, 1978).

During the phase of the conception of the entrepreneurial idea, resources must support various intangible content activities (market analysis, research and development, recruitment) to determine the cost effectiveness of the project itself (Winter, 1987; Itami, 1988; Guatri, 1989; Vicari, 1989; Parr, 1992; Rullani, 1992; Bruni \& Campedelli, 1993; Buttignon, 1993; Chiacchierini, 1995; Vicari, 1995; Corno, 1996; Ferrando, 1998; Fontana, 2003). During this stage, the financial needs are directly covered by the founder although it is conceivable the access to funds available for this purpose (seed capital), or provided by state, regional and local public authorities.

The startup stage of the company in a certain sector/market is characterized by a high degree of uncertainty about chances of success of the business idea and the capital requirement is remarkable because of the substantial absence of revenues. The financial resources are destined to the working capital and the preparation of the production capacity (estates, plants, machinery, equipment, advertising and promotional campaigns, etc.). 
However, it persists a situation of considerable risk, where possibilities to draw on the debt capital are precluded or not adequate compared to the increasing financing needs due to insufficient information about the company's history and the business project.

In the development phase, during which the risk level begins to decrease, while the financial gap continues to grow, it is appropriate to continue to use even venture capital in order to maintain an appropriate financial balance. Once overcome the previous phases considered "critical", businesses usually tend to diversify their funding sources, as information asymmetries are reduced and the company has increased its reputation at a level that enables it to turn to the financial market.

The so-called "expansion phase" determines the transition to the stage of the "corporate maturity" characterized by the consolidation and development of the business project. Since the market reacts positively, with consequent positive and increasing flows arising from the current management, the risk degree of the plan continues to decrease, even if the requirements to reach an optimal size in structural and operational terms is huge.

This situation continues until cash flows from the current management do not contract up to a level that will trigger the phase of decline.

The composition of financial needs, which varies from company to company, based on the peculiarities of the sector and on the operating ones too, states Sciarelli (2011), must constantly meet, over time, actual and structural needs, extraordinary needs in the long term and short-term needs characterized by occasionality, contingency and unpredictability.

\section{The Financial Function in Businesses}

In the current context, the organizational boundaries of the corporate function responsible for the financial management have expanded and gained an increasing importance in the value chain of the businesses.

For Brugger (1979) "The specific content of the function is subject to change as a result of the evolution of the business issue, the type of organizational structures, the systems of tasks, concepts and techniques available".

Over time, this function evolved into a strategic financial model, which always interacts with the other areas of the management during corporate life when objectives and strategies must be defined.

The continuous need to support competitiveness, the external development policies, the reorganization of groups with transformations of the operating companies in financial holdings through spin-off processes, the intensification of extraordinary financial operations, enhance the strategic dimension of the financial choices (Paravani \& Tagliavini, 2006).

To the usual tasks of resources procurement, typical for the financial function, necessary to cover the financial requirements within the best possible economic conditions and in compliance with the overall risk, were added:

- The optimization of investment planning, which is a main aspect of the entrepreneurial strategy since a good industrial development project must be financially sustainable;

- Fulfillment of an adequate financial flexibility (Sandri, 1994);

- Creation of a coherent and effective system of intra-systemic relations (and inter-systemic too), aimed to take early appropriate decisions according to the company needs and contingencies arising from the dynamism of a market;

- The centralizing of decision-making processes in order to use financial resources which, if properly managed, help to improve the results of the enterprise through a better bargaining power against intermediaries, a more effective planning and control of financial flows, control of financial costs and risk in exchange and interest rates, in order to reach the direct production of financial services able to free the customer from the duty to directly look for the coverage of financial needs (Golinelli, 2003);

- Tactical and operational requirements, addressed to the implementation and control of the decisions taken and to the definition of general policies for the management. In this context, the financial manager, in agreement with other appointed corporate departments (Solomon, 1963), must take care of the credit relations with customers, establish the terms and conditions of payment with customers and suppliers, manage the movable assets and real estate of company, and verify the feasibility of the investment projects. $\mathrm{He}$ is also required to express his opinions on sale prices, on the implementation of extraordinary operations and operations abroad, etc.

This view leads to consider the company as a set of cross-cutting processes, which crosses the organizational boundaries, both internally and externally (Golinelli \& Dezi, 1998). 
Thus it becomes relevant the role of finance in co-determining the success conditions.

If the financial function must primarily deal with the capital, from the moment in which it is necessary to make decisions about its supply and its use, it also affects the functions of the non-financial corporate system relating to the real management. This real activity could not pursue the business purposes if it were not interrelated with financial management; it must determine and coordinate financial-monetary flows that precede, accompany and follow the development of the economic management, that is the synthesis of the real activity. The entity of these funds and cash flows can affects the liquidity and the dynamic evolution of the company, causing crisis despite positive economic results as a result of malfunctions (Pochetti, 1989).

Once fulfilled the treasury function, financial management becomes a parallel activity for the profits generation too. In this phase, the surplus pro tempore of financial resources is used in the short term for the best performance possible, consistent with the needs of the operations (Panati \& Golinelli, 1999). It contributes indeed to increase corporate profitability through purely financial activities sustained by both the attractive real rates of financial investments and the arbitrage opportunities arising from the increasing bargaining power that the large companies show towards the banks, the inefficiencies of the latter and the imperfections of the financial markets (Paravani \& Tagliavini, 2006).

In many companies, and especially in those of small size, the importance of the financial function is strongly neglected, considering it an almost exclusively privilege of large companies. In these situations, the entrepreneur-owner personally manages only the essential, fundamental tasks related to finance required to meet ex-post the funding needs of projects investment, using elementary financial instruments often coming from banks. The frequent intervention of a sort of family control in the government of smaller companies often subordinates the company finance to "the family" one.

Such a short-sighted view leads to situations of tension or to real financial crisis, which unfortunately characterizes the Italian economic system (Dallocchio, 1995).

In absence of a correct prediction of the dynamics of collections and payments and of an accurate assessment of the cash flows, that an additional investment plan could generate, the company will have to face a situation of dissonance with the banks and the other funders.

When the evolutionary dynamics of the business system becomes more complex, as a result of the diversification of strategic business areas, internationalization, tendency to innovate, actions aimed at restoring, decline in profit margins, a more intense competition that leads to an accurate management "control" of financial flows, instability and dynamism of the capital market characterized by strong competition between borrowers and lenders of funds, the corporate finance gains an emphasized importance and becomes strategically relevant (Brunetti, 1984). This relevance gains importance because, while it has to support and promote the fundamental direction of the company, it also must find the financial resources and has to acquire instruments and especially skills able to optimize the government of the company resources (Forestieri, 2011).

In the end, it is important to emphasize that the financial function, while monitoring constantly the context, is able to transfer other information to the remaining departments (about competitors, the macroeconomic situation, the evolution of laws and quotations); these, properly processed and classified, allow the preparation of a well-founded and structured financial planning. This planning must be implemented both through the preparation of strategic plans of business conduct, that must cover a long-term period of time, and also through detailed projects, relating to the short and medium term and aimed at raising external funds to an extent that does not compromise the financial balance of management and allows to respect the economic balance (Pochetti, 1989).

The planning entails a government matrix of the overall funds flow in connection with the economic and financial decisions that fulfills corporate policies in the framework of the strategies pursued. The goal is to verify the financial compatibility of the company evolutionary dynamic, in order to relate the financial needs with the ability to internal and external financing, in compliance with the balance conditions between funding sources and between these ones and the duration of the respective cycles, as well as the relationship between risk and return pursued by the economic entity. This activity is the highest contribution of the financial function in the achievement of the systemic purposes (Paravani \& Tagliavini, 2006). However, SMEs are not so often oriented towards forms of real coordination between the needs and the most effective financing method. This phenomenon is mainly related to an insufficient financial culture and reduced knowledge and expertise on alternatives to bank credit (Ciampi, 1994).

As Panati and Golinelli (1999) highlighted, it is a huge mistake to underestimate the financial problem, merely dealing with it only when the economic situation is negative, since in the enterprise the financial function is taking on a growing importance within its value chain. 


\section{Funding Sources: The Need to Trigger a Intersystemic Relationship between Banks and Businesses}

In order to meet the needs of financial resources, the governing body of the company must base the selection process on the objectives of economic efficiency, uniformity, elasticity and flexibility. This process can be considered as a variable dependent on the financial requirements, or as an independent variable, and in this case the same need can change when taking into account the evolutionary dynamics and the level of debt to be achieve.

The starting point bases on an indebtness level that can be considered acceptable for the company, in terms of quality relating to risk and rigidity resulting from the increased debt position, and in terms of leverage (Solomon, 1972). However, despite the financial leverage can be considered a useful tool in the evaluation of the debt level to take on, the choice between own and third-parties resources must also take into account other factors (Capaldo, 1967):

- The financial feasibility of a loan. Financial burdens that must remunerate the loan capital or the dividends to distribute to the venture capital investors, along with any capital reimbursements, will generate the output streams for which it is necessary to provide adequate forms of coverage to avoid impairment of the business financial balance. Where impossible, the financing form, although cheaper, is not financially feasible (Dallocchio, 1995);

- The degree of financial elasticity: a high degree if this factor allows the system "enterprise" to have many possibilities of choice. In such a case it can cover requirements by changing the mix of loans, increasing the short-term debts or long-term ones, raising new risk capital, through contributions of the shareholders or by directly turning to the market (Dallocchio, 1995);

- As the level of indebtedness raise, the financial burdens increase and this contains the net income, while the financial risk of the enterprise increases too;

- The needs of the economic entity, related to privacy and control maintaining over the business, both in terms of equity stake and interference in the management of the shareholders' meeting (Metallo \& Pencarelli, 1995);

- The tax advantage resulting from the deductibility of the interest expenses from taxable income can be nullified if the enterprise obtains negative net results. However, the tax variable is crucial to the economic evaluation of a financing form. It can overturn the judgment of convenience for the benefit of a method that might look like less convenient when superficially analyzed (Dallocchio, 1995).

The selection of the funding arrangements must also take into account the different deadlines depending on the characteristics of the coverage (a part of the financial requirement is durable and should typically be covered by equity capital and by the consolidated liabilities, while the share on the assets must be covered by the current liabilities) and on the different types of restriction. There should be considered, in this last case, the dimensional characteristics and the legal form of the company to the extent required by regulations, the Civil Code, and for the habits established over time on the financial markets (Alberti, 1977). This last condition differentiates the financial perspective of a sole proprietorship and of a company.

Sole proprietorships encounter considerable difficulties in accessing credit, especially the long-term one, due to the uncertainty on the life of the organization. They mainly finance the company's activities with the capital brought in during the establishment phase or with later interventions of the entrepreneur, who takes on duty of all losses, and benefits from the profits that may arise from the management.

The companies are supported by the fragmentation of business risks among multiple subjects and the ability to find a higher volume of financial resources. They can, among other things, turn to the market through the issuance of typical financial instruments, provided by the Civil Code, with an atypical content, while identifying the most convenient combinations for the features of the enterprise and investments to be made, or by modifying over time these combinations and adapting them to the changing business needs and to the varied economic and financial market conditions. In particular, the size of the company represents a barrier within the possibilities of access to financial services characterized by a high level of specialization and added value. These conditions limit the growth and affect the phenomenon of fragmentation of enterprises (Forestieri, 2011).

Within the restrictions to comply with, it is necessary that the impact on equity exceeds the debt capital, and therefore the total capital invested, in order to prevent external stakeholders to take decisions according to the ways in which the enterprise is financed and, in this way, to affect the overall business management (Dallocchio, 1995).

Companies may turn to internal or external funding sources or, in case of inability, may review the entrepreneurial strategies. For the purposes of this study, it is appropriate to focus on the sources with exogenous origin. They 
typically are constituted by venture capital, provided by the property as part of the primary equipment in order to pursue the systemic goals, and by the internally self-financing generated by the management they are permanently employed in the company. Especially the more structured companies may also turn to the securities market or exploit the resources acquired through:

- A financial company;

- Merchant bank. "among financial companies, associates mainly have holdings in the financial sector, as well as those that mainly have holdings in the industrial sector when their role is "merchant banking" and therefore characterized by the activities of counseling and financial assistance of the 'enterprise'. "the companies that play the role of merchant banking, essentially characterized by the fact that the shares are acquired with the finality of subsequent disposals, can be brought back to the category of "merchant banking" (Bank of Italy, 1999);

- Private equity. These funds invest in "patient" capital to support the development of unlisted companies. The private equity funds provide a medium-term time lapse to allow all business to grow and reach the goal of its strategic plan. In addition to providing financial resources, they share international networks, knowledge, skills, management and operational experience, facilitating relations with the financial system and paying great attention to the development of long-term sustainability and continuous value creation. The private equity can be exploited to solve the problems associated with the ownership of a company or with the phenomenon of generational change. Moreover, it is the preferred solution for the realization of buy-out / buy-in, carried out by experienced managers (Aifi, 2011).

- Business angels (Wetzel, 1986; Mason \& Harrison, 1995; Mason \& Harrison, 1999; Mustilli, 1999; Mason \& Harrison, 2000; Sohl et al., 2000; Trotta, 2001; Malte, 2002; Mason \& Harrison, 2002; Sorrentino, 2003a; Maggioni \& Sorrentino, 2003; Kotler et al., 2004; Markku et al., 2005; Sorrentino, 2006). Natural persons who invest their capital not only for financial purposes (Sullivan \& Miller, 1996), in a confidential, anonymous and very quickly way, or in a business project in high strategic value areas since the earliest stages of the startup, they also undertake a high risk that will be "compensated" with an above average return. This method overcomes the limitations arising from a high level of asymmetric information (Akerlof, 1970; Amit et al., 1990) and poor adherence to the commonly recognized company evaluation criteria, which limit the access to the external funding sources; this allows the business culture of many young entrepreneurs to develop (Aifi, 2011). The angel is actively involved in the management of the enterprise funded by controlling any opportunistic behavior of the entrepreneurs after the loan has been granted (the so-called moral hazard ) (Sorrentino, 2006);

- Early stage financing. It concerns the financing of the initial phase of an entrepreneurial activity. It can be divided into seed financing and start-up financing (Barontini \& Caprio, 2000). In the first case, investors, highly specialized in the evaluation of the entrepreneurial team and the target market even finance the business idea. In the second case they finance activities of a company that was formally created and has an established governing body. In this case, the product / service has been already developed, albeit at a prototype stage, and very often it has been already patented as well as validated by the market research; however, it has not yet been tested in commercial terms (Aifi, 2011). This method of supply the financial resources is highly dangerous due to experimentation of an innovative idea that generates a high level of uncertainty and variance of the predetermined objectives (Stinchcombe, 1965);

- Venture capitalists (Sahlman, 1990; Coopers, et al., 1996; Coopers \& Lybrand, 1997; Mustilli, 1999; Nuechterlein, 2000; Szego, 2002), in the role of institutional and non-institutional investors, able to support companies both in financial and managerial terms (Peirone, 2007). They have been defined by EVCA (european private equity \& venture capital association) as "a professional equity co-invested with the entrepreneur to fund an early-stage (seed and start-up) or expansion venture. Offsetting the high risk the investor takes is the expectation of higher than average return on the investment". These entities collect funds on the market, from public and institutional investors, to use them in a pre-defined period, usually of medium and long term, by way of risk capital in companies not listed, however yet highly innovative with big development potentials of the business and high probability of a return on the capital provided;

- "Alternative" financial markets; using, in particular the Italian aim / alternative capital market (aim Italy / mac), through a simplified procedure regulated and managed by the Italian stock exchange, these are able to allow the SMEs with high growth potential to directly acquire the resources which finance the evolutionary dynamics (Miglietta et al., 2010).

The opening of the system "enterprise" towards an increase in the weight and quality of the external funding 
sources, implemented through the dissemination of venture capital, offers SMEs the opportunity to develop the evolutionary dynamics with higher growth rates than it would be possible only taking advantage of the financial availability of the owners.

In a context characterized by increasing market integration and the adoption of strategies aimed to internationalization, the listing improves the reputation and social consensus of businesses domestically and internationally, industrially and financially.

When a situation of geographical proximity between borrowers and lenders occurs, "virtuous" relationships are often established to improve the social legitimacy of the entity by the systemic stakeholders. This originates a double effect: the enterprise undertakes a strong sense of social responsibility towards the environment; the subscribers of the risk capital perceive the titles issued by minor enterprises not as "assets", but as titles representing a system "enterprise" that somehow "belong" to them because of the employment, professional or supply relationships (Metallo \& Pencarelli, 1995).

The status of "listed" company generates greater confidence in the stakeholders operating in the competitive system, because they are aware of the controls this kind of company is subject to. The listing provides, in fact, the application and the respect of precise and transparent rules of corporate governance that gradually "de-costumize" and institutionalize systemic entities, especially in cases of family businesses.

This status accompanied by a higher level of capitalization also creates a positive effect upon the propensity to grow through acquisitions and the creditworthiness and the standing of SMEs towards the financial system through: better access to credit, which allows the exploitation of the leverage, greater bargaining power towards intermediaries, an increase in the supply channels of the financial resources, tools and techniques that can be used.

Turning to risk capital, as a whole, helps to assess the bankability of a company, the stability of the management and the profitability of the economic entity (Giampaoli, 2000).

To traditional forms of financing and management of financial resources, innovative financial engineering instruments establishing "complementary" opportunities in the capital market for companies operating in modern society have been recently added. The equity-based Crowdfunding falls under this context: using the Internet platform, it has the ability to raise equity and to share the business risk, in the startup phase, among a "dense network" of investors / consumers of small size (Belleflamme et al., 2012). Its principles define a new relationship between entrepreneurial and lending activity, offering both benefits not found in other financing methods, such as a more efficient timing for the access, the absence of intermediaries, a satisfactory return on invested capital and the evaluation of business plans both from investors and the potential consumers (Miglietta et al., 2013).

The Crowdfunding (Note 1), in the equity based version (Castrataro et al., 2012), compensates the increasing problems of credit, by presenting itself as a valid alternative, especially for innovative startups which, not having adequate collateral or stable cash flows able to support the return on the capital borrowed, are severely limited in the access to credit (Berger \& Udell, 1998). It is a "catalyst" and "accelerator" for this type of companies, "which, penalized by the lack of traditional funding, suffer in macroeconomic terms the interruption of investments in research and development of our system, since very often the activities of the contemporary startups have a high technological innovation profile, such as the biomedical sector and ICT" (Miglietta et al., 2013). It has the ability to value the most promising projects inhibiting those that tend to be less competitive on the basis of the applications received, reducing the possible dead times preceding the implementation of the business idea (Wash \& Solomon, 2011; Mollick, 2012). As part of the external sources, a prominent role is played by the bank debt that notoriously can differ for time extension and technical forms. The typical short-term forms are characterized by the openness to credit, bank advances, advances on invoices and bank receipts, discounted bills and contingent credit. On the contrary, technical forms of financing with a medium to long term, are destined to investments on fixed assets (buildings, machinery, equipment) or policies of external growth fulfilled through extraordinary mergers, acquisitions, etc. It is good to point out that, for the businesses, the availability of financial durable sources is the condicio sine qua non to make investments in research and development possible (R\&D) as well as for the promotion of innovative business projects, in order to pursue and/or strengthen the competitive advantages. In these cases, the banks have to make a thorough analysis of the corporate management, accompanied by a precise evaluation of the validity, in profitability and financial terms, of the planned investment projects. Into this category typically fall mortgages, leasing, project financing and factoring.

These methods offer the lender a higher level of risk than the short-term loans because of the complexity and uncertainty in making predictions: the longer the loan, the more uncertain the predictions. In these cases, beyond the fiduciary relationship, the borrower must provide collateral guarantees, such as the mortgage on real or personal property. 
Finally, into the forms of financing also fall the so-called hybrid financial instruments that blend debt's elements with those of the actions, such as convertible bonds, subordinated loans and operations of mezzanine finance.

\section{The Order of the Choice between the Different Funding Sources in Accordance with the Pecking Order Theory}

Financial activity is notoriously and endemically exposed ex ante (in the selection process) and ex post (in the monitoring phase of the counterparty's ability to meet its commitments) with respect to the contractually provided interaction with the borrower because of informative asymmetries.

Informative asymmetries occur when on the market imperfections arise, in a way that the counterparties involved in an agreement does not have access to the same amount and type of information (Myers \& Majluf, 1984; Narayanan, 1998). This situation affects the efficiency and allocative evaluation of the credit market (Bolton \& Freixas, 2000). These forms of efficiency are influenced by the limited rationality of investors expressed through cognitive limitations in managing the complexity, the availability of relevant information, the costs of research, acquisition and processing of such information. From the above assessment it emerges that, in case of inefficiency of the financial markets, the pricing of the transaction does not reflect exactly the trade-off between risk and return.

This situation impact the screening of investment projects to be financed by generating inefficient allocations (low or excessive credit) (Mirrlees, 1971; Rothschild \& Stiglitz, 1976; Stiglitz \& Weiss, 1981; Maskin \& Riley, 1984; Bester, 1985).

The opacity of the inter-systemic relations, in this case between units and deficit units in surplus capital, can generate opportunistic behavior by the entity that has the information advantage, resulting in adverse selection (Akerlof, 1970) and moral hazard.

Adverse selection occurs during the pre-contractual phase when, in the presence of strongly asymmetric information between the actors, the worst projects are chosen (Akerlof, 1970; Mirrlees, 1971; Amit et al., 1990). In these circumstances the phenomenon of "credit rationing" arises regardless of the interest rate that the enterprise can pay (Stiglitz \& Weiss, 1981; Armendariz de Aghion \& Gollier, 1981). In order to limit the perverse consequences of the price on quality, it emerges a situation of excess demand over the supply of credit.

The moral hazard occurs when the "good faith" of the borrower fails, because he intentionally doesn't repay the borrowed funds or does not fulfill its contractual obligations. This not only obstacles the free development of the market mechanisms, but also sustains the modus operandi of the banking system.

These problems can be overcome if a close interaction between enterprise and financial system can be established, by reducing the information gap through a constant and global communication concerning the real risk conditions of the enterprise, thereby promoting the access to the capital market.

Asymmetric Information influence, therefore, the selection between endogenous and exogenous funding, including debt and equity. However, as asserted by Fontana and Caroli (2009), this choice should be subject to the achievement of the systemic purpose of the creation of the company value, taking into account the influence of tax and agency costs typical for each source.

This approach converges with the Pecking Order Theory developed by Myers and Majluf in 1984 (Fama \& Fench, 2000; Murray \& Goyal, 2003; Abu Jalal, 2007). According to the theory of the order of choice, companies meet a sort of ranking, concerning the funding choices, on the basis of the market and their exposure to the information opacity risks. To finance the financial requirements indeed, the enterprises prefer the domestic financial sources represented by retained earnings and by the contributions made by shareholders, which have a lower degree of information asymmetry and financing cost. Only at a later stage, in case of cash imbalance, they turn to the external financing typically represented by debt bank and, ultimately, to the capital increase fulfilled by the issue of new shares which requires a higher level of information transparency and the undertaking of heavier costs with a pro-cyclical pattern: "the premium payable for external funding increases in slowdowns and decreases during growth" (Carpinelli, 2009). To prefer the debt to equity implies an increase in leverage. This "choice order" is preferred because the system "enterprise" can take advantage of the benefits arising from a situation of flexibility, which makes it able to timely face the stresses arising from the reference context and the control of the ownership.

The hierarchy in the financing choices indicated by the Pecking order theory, as stated by Modina (2010), with the conclusion of the Basel Accords, that force the financial system to assess the creditworthiness of the counterparty, partially loses its validity. To check the rating category assigned or to improve it, the company uses most frequently the financing through venture capital rather than a debt security, despite being the first one more expensive than the latter. 


\section{Conclusions, Managerial Implications and Suggestions for Future Research}

Analyzing literature related to the empirical studies, various criticalities emerge toward the capital of the enterprises, its evaluation and interpretation as an exchange tool on the markets.

A poor capital increases the vulnerability of the enterprise that not always can cover all the risks it has taken on (among them: operational, market, credit, liquidity, reputational risks and most of all the risk relating to the lack of knowledge); this could trigger huge impacts both on the individual and on the social economy. However, a wise risks management, at the ethical level, where the risks relate to the economic sector the enterprise belongs to, is often affected by the specific perceptions of the Government who must be able to determine adequate resources to face the risks and that could include them into the category of "manageable treats".

This situation is a contributory cause -together with other structural and contingency factors- of the excessive short-term debt as well as of the persistent preference of debt policies to the acquisition of full risk debt capital.

Moreover, it exposes the Italian entrepreneurial sector, more than the European one, to the financial shocks, generating heavy consequences on the competitiveness of our nation. It affects the risk profile and so the profit the investors/funders expect, and moreover the reputation of the enterprise.

This situation is associated to a third wrong use of the instruments that should finance the entrepreneurial activity, that is, the lack of correlation between Sources and Uses.

The methods to finance an investment are extremely important because they allow to improve the economic result thanks to a lower cost of the capital used. Furthermore, for a cost-effective investment, it is necessary a certain financial viability, namely the ability to find the necessary resources. All this, however, must be fulfilled in a balanced way, so that there won't be an excess of financial risk, which would nullify the economic benefit of a lower cost of the capital; at the same time the whole operation should not be made too complex because of the excessive restrictions required to the investors. With regard to the future research, it is suggested to empirically investigate how much enterprises - especially the small ones - actually use the innovate methods of capitalization as well as the impacts generated by these strategies on improving credit standing.

Moreover it is planned to increase the topic dealt in this paper by the elaboration of a calculation system for the quantification of the minimum capital required to allocate to cover the risks taken on by the enterprises, according to the activity sector and the peculiar characteristics of the company.

\section{References}

AIFI. (2011). Libro bianco. Proposte per lo sviluppo del venture capital in Italia.

Akerlof, G. A. (1970). The market for "Lemons": Qualitative uncertainty and the market mechanism. Quarterly Journal of Economics, (89), 488-500. http://dx.doi.org/10.2307/1879431

Alberti, G. (1977). Finanziamento e forma giuridica delle imprese. Milano, Italia: Isedi.

Amit, R., Glosten, L., \& Muller, E. (1990). Does venture capitalist foster the most promising entrepreneurial firms? California Management Review, Spring, 102-111.

Armendariz de Aghion, B., \& Gollier, A. (1981). Credit rationing in markets with imperfect information. American Economic Review, (71), 393-410.

Banca d'Italia. (1999). Istruzioni di Vigilanza, Titolo IV, Cap. 9.

Barile, S. (2008). L'impresa come sistema - Contributi sull'Approccio Sistemico Vitale. Torino, Italia: Giappichelli.

Barile, S. (2011). L'approccio sistemico vitale per lo sviluppo del territorio. Sinergie, (84), 47-87.

Barile, S., \& Golinelli, C. M. (2008). Modalità e limiti dell'azione di governo del territorio in ottica sistemica. In S. Barile (Ed.), L'impresa come sistema: Contributi sull'Approccio Sistemico Vitale (ASV) (pp. 243-268). Torino, Italia: Giappichelli.

Barontini, R., \& Caprio, L. (2000). Le risorse per lo start-up e per l'innovazione. Il ruolo della finanza nella PMI. In A. Lipparini, \& G. Lorenzoni (Eds.), Imprenditori e imprese. Idee, piani, processi (pp. 77-102). Bologna, Italia: Il Mulino.

Beer, S. (1969). Cybernetics and management. London: English University Press Ltd.

Beer, S. (1973). L'azienda come sistema cibernetico. Milano, Italia: Isedi,

Beer, S. (1991). Diagnosi e progettazione organizzative - Principi cibernetici. Milano, Italia: Isedi. 
Belleflamme, P., Lambert, T., \& Schwienbacher, A. (2012). Crowdfunding: Tapping the right crowd. CORE Discussion Paper, 2011/32, 1-40. http://dx.doi.org/10.1016/j.jbusvent.2013.07.003

Berger, A. N., \& Udell, G. F. (1998). The economics of small business finance the roles of private equity and debt markets in the financial growth cycle. Journal of Banking and Finance, 22(6-8), 613-673. http://dx.doi.org/10.1016/S0378-4266(98)00038-7

Bester, H. (1985). Screening vs. rationing in credit markets with imperfect information. American Economic Review, (57), 850-855.

Birindelli, G., Modina, M., Maiorano, L., \& Di Ciero, N. (2010). Banche e imprese: Un'indagine sul territorio molisano. In G. Birindelli, \& M. Modina, (Eds.), Imprese, Banche e Finanza. Le evidenze di un'analisi territoriale alla luce della crisi finanziaria (pp. 189-227). Milano, Italia: Franco Angeli.

Bolton, P., \& Freixas, X. (2000). Equity, bonds and bank debt: Capital structure and financial market equilibrium under asymmetric information. Journal of Political Economy, 108(2), 324-351. http://dx.doi.org/10.1086/262121

Brugger, G. (1979). La funzione finanziaria nell'impresa. Milano, Italia: Franco Angeli.

Brunetti, G. (1974). Le decisione finanziarie nell'economia d'impresa. Milano, Italia: Franco Angeli.

Brunetti, G. (1984). Evoluzione e recenti tendenze di sviluppo della finanza aziendale. Atti del Convegno AIDEA, Cagliari 11 e 12 ottobre 1984. Bologna, Italia: Clueb.

Bruni, G., \& Campedelli, B. (1993). La determinazione, il controllo e la rappresentazione del valore delle risorse immateriali nell'economia dell'impresa. Sinergie, (30), 89-101.

Buttignon, F. (1993). Le risorse immateriali: ruolo strategico e problematiche di rilevazione. Sinergie, (30), 103-133.

Capaldo, P. (1967). Capitale proprio e capitale di credito nel finanziamento dell'impresa. Milano, Italia: Giuffrè.

Carpinelli, L. (2009). Effetti reali delle crisi bancarie: Una rassegna della letteratura. Questioni di Economia e Finanza. Occasional Papers, n. 55, Roma, Italia: Banca d'Italia, Settembre, pp. 1-31.

Castrataro, D., \& Pais, I. (2012). Analisi delle piattaforme di CrowdFunding Italiane. Il sole 24 Ore special, Novembre, 1-16. Milano, Italia.

Chiacchierini, C. (1995). Valore dei beni immateriali e vantaggio competitivo. Padova, Italia: Cedam.

Ciampi, F. (1994). Squilibri di assetto finanziario nelle piccole e medie imprese. Studi ed Informazioni, Supplemento al, (3), 1-202.

Coopers \& Lybrand LLP. (1997). The economic impact of venture capital in Europe. Belgium, EVCA.

Coopers \& Lybrand/Venture One. (1996). Seventh annual economic impact of venture capital study. NVCA, Arlington, VA.

Corno, F. (1996). Patrimonio intangibile e governo d' impresa. Egea, Milano.

Dallocchio, M. (1995). Finanza d'azienda. Analisi e valutazioni per le decisioni d'impresa. Milano, Italia: Egea.

Esposito De Falco, S. (2003). Competizione Globale e forme di potenziamento della governance. Sinergie, (60), 163-188.

Fabozzi, F., \& Modigliani, F. (1995). Mercati finanziari. Istituzioni e strumenti. Bologna, Italia: Il Mulino.

Fama, E., \& Fench, K. (2000). Testing trade off and pecking order predictions about dividends and debt. The Review of Financial Studies, 15(1), 1-33. http://dx.doi.org/10.1093/rfs/15.1.1

Ferrando, P. M. (1998). Risorse e risorse immateriali. Natura e implicazioni per il valore dell'impresa. In P. M. Ferrando, L. Fadda, \& R. P. Dameri (Eds.), Saggi sull'immaterialità nell'economia delle imprese(pp. 1-50). Torino, Italia: Giappichelli.

Fontana, F. (2003). Le risorse immateriali nella comunicazione aziendale: Problemi di valutazione e di rappresentazione nella prospettiva del valore. Torino, Italia: Giappichelli.

Fontana, F., \& Caroli, M. (2009). Economia e Gestione delle Imprese. Milano, Italia: McGraw Hill.

Forestieri, F., \& Mottura, P. (1998). Il sistema finanziario. Milano, Italia: Egea.

Forestieri, G. (1993). Banche, intermediazione finanziaria e finanza. Milano, Italia: Egea. 
Forestieri, G. (2011). Corporate \& investment banking. Milano, Italia: Egea.

Formisano, V. (2002). La dinamica evolutiva dell'impresa bancaria: Una lettura in chiave sistemico-vitale. Dimensione, teoria delle risorse, network. Quaderno n. 19, Dipartimento Impresa e Lavoro, Università degli Studi di Cassino.

Giampaoli, A. (2000). Banca e impresa. Milano, Italia: Egea.

Giannessi, E. (1982). L'equazione del fabbisogno di finanziamento nelle aziende di produzione e le possibili vie della sua soluzione. Milano, Italia: Giuffrè.

Golinelli, G. M. (2000). L'approccio sistemico al governo dell'impresa. L'impresa sistema vitale, 1. Padova, Italia: Cedam.

Golinelli, G. M. (2000). L'approccio sistemico al governo dell'impresa. La dinamica evolutiva del sistema tra economia e finanza, 2. Milano, Italia: Cedam.

Golinelli, G. M. (2003). Economia e finanza nel governo dell'impresa. Sinergie, (61-62), 227-253.

Golinelli, G. M. (2009). L'approccio sistemico vitale: nuovi orizzonti di ricerca per il governo dell'impresa. Sinergie rivista di studi e ricerche, (79), XI-XXIV.

Golinelli, G. M., \& Dezi, L. (1998). Reti, finanza, progetti. Padova, Italia: Cedam.

Golinelli, G. M., \& Gatti, M. (2005). Il pensiero di Roberto Fazzi e l'approccio sistemico al governo dell'impresa: Spunti di riflessione tra debito culturale, avanzamento dottrinale e spirito del tempo. Sinergie, (67), 207-255.

Guatri, L. (1989). Il differenziale fantasma: i beni immateriali nella determinazione del reddito e nella valutazione delle imprese. Finanza, Marketing e Produzione, (1), 53-61.

Itami, H. (1988). Le risorse invisibili. Torino, Italia: Isedi.

Jalal, A. I. M. (2007). The pecking order, information asymmetry, and financial market efficiency. ProQuest.

Kotler, P., Kartajaya, H., \& Young, S.D. (2004). Attracting investors: A marketing approach to finding funds for your business. New Jersey: Wiley.

Maggioni, V., \& Sorrentino, M. (2003). Il finanziamento delle piccole imprese ad elevata innovazione: Il ruolo dell'informal venture capital. In R. Cafferata (Ed.), Imprese italiane internet. Milano, Italia: Franco Angeli.

Malte, B. (2002). German business angel in international comparisons. Journal of Private Equity, 5(2), 53-67.

Markku, M., Erkko, A., \& Pia, A. (2005). What drives micro-angel investments? Small Business Economics, 25(5), 459-475. http://dx.doi.org/10.1007/s11187-004-2278-4

Maskin, E., \& Riley, J. (1984). Monopoly with incomplete information. Rand Journal of Economics, 15(2), 171-196. http://dx.doi.org/10.2307/2555674

Mason, C. M., \& Harrison, R. T. (1995). Closing the regional equity capital gap: The role of informal venture capital. Small Business Economics, 7(2), 153-172. http://dx.doi.org/10.1007/bf01108688

Mason, C. M., \& Harrison, R. T. (1999). Public policy and the development of the informal venture capital market. In K. Cowling (Ed.), Industrial policy in Europe: Theoretical perspectives and practical proposition (pp. 199-223). London, England: Routledge. http://dx.doi.org/10.4324/9780203103098.pt4

Mason, C. M., \& Harrison, R. T. (2000). Investing in technology ventures: What do business angel look for at the initial screening stage? Paper to the 20th Babson-Kauffman Foundation Entrepreneurship Research Conference, Babson College, 8-10 June.

Mason, C. M., \& Harrison, R. T. (2002). Barriers to investment in the informal venture capital sector. $\begin{array}{llll}\text { Entrepreneurship and Revional 271-287. } & \text { Development, }\end{array}$ http://dx.doi.org/10.1080/08985620210142011

Metallo, G., \& Pencarelli, T. (1995). I circuiti finanziari tra localismi e globalizzazione. Verso un'integrazione. Milano, Italia: Giuffrè.

Miglietta, A., Parisi, E., Pessione, D., \& Servato, F. (2013). Crowdfunding and local administation: A financial oppotunity for a new liason with citizens. Presentazione al Toulon Verona Conference 2013 - Excellence in service, Lubiana, Slovenia.

Miglietta, A., Peirone, D., \& Servato, F. (2010). L'efficienza del sistema locale di innovazione piemontese tra 
governance e problematiche finanziarie. Sinergie, (83), 77-97.

Mirrlees, J. A. (1971). An exploration in the theory of optimal income taxation. The Review of Economic Studies, 38(2), 175-208. http://dx.doi.org/10.2307/2296779

Modina, M. (2010). Ricorso al debito e rapporto banca-impresa: Un inquadramento teorico. In G. Birindelli \& M. Modina (Eds.), Imprese, banche e finanza. Le evidenze di un'analisi territoriale alla luce della crisi finanziaria (pp. 15-63). Milano, Italia: Franco Angeli.

Mollick, E. (2013). The dynamics of crowdfunding: Determinants of success and failure. SSRN Electronic Journal. http://dx.doi.org/10.2139/ssrn.2088298

Mottura, P. (1996). La transizione della banca da un sistema amministrato al mercato competitivo. Banche e Banchieri, (1), 9-19.

Murray, Z. F., \& Goyal, V. K. (2003). Testing the pecking order theory of capital structure. Journal of Financial Economics, 67(2), 217-248. http://dx.doi.org/10.1016/s0304-405x(02)00252-0

Mustilli, M. (1999). L'evoluzione del venture capital nello sviluppo delle piccole e medie imprese. Padova, Italia: Cedam.

Myers, S. C., \& Majluf, N. S. (1984). Corporate financing and investment decisions: When firms have information that investor do not have. Journal of Financial Economics, 13(2), 187-221. http://dx.doi.org/10.1016/0304-405x(84)90023-0

Narayanan, M. (1998). Debt versus equity under asymmetric information. The Journal of Financial and Quantitative Analysis, 23(1), 39-51. http://dx.doi.org/10.2307/2331023

Nelson, R., \& Winter, S. (1982). An evolutionary theory of economic change. Cambridge (MA): Harvard University Press.

Nuechterlein, J. D. (2000). International venture capital: The role of start-up financing in the United States, Europe, and Asia. In P. DeSousa (Ed.), Economic strategy and national security (pp. 2-27). Boulder, Co: Westvie Press.

Onado, M. (2004). Economia e regolamentazione del sistema finanziario. Bologna, Italia: Il Mulino.

Panati, G., \& Golinelli, G. M. (1999). Tecnica economica industriale e commerciale. Imprese, Strategie e Management, 2. Roma, Italia: Carocci.

Paravani, E., \& Tagliavini, G. (2006). Pianificazione finanziaria. La gestione della solvibilità e del valore. Milano, Italia: McGraw-Hill.

Parr, R. L. (1992). Investing in intangible assets: Finding and profiting from hidden corporate value. New York, NY: J. Wiley \& Sons.

Peirone, D. (2007). Knowledge and venture funding: Complementarities and financial contracts. Industrial and Corporate Change, 16(5), 851-873. http://dx.doi.org/10.1093/icc/dtm029

Pochetti, G. (1989). Finanza aziendale. Torino, Italia: Utet.

Previati, D. (1988). L'integrazione della funzione finanziaria nella strategia della PI. Piccola Impresa/Small Business, (1), 33-65.

Rothschild, M., \& Stiglitz, J. (1976). Equilibrium in competitive insurance markets: An essay on the economics of imperfect information: Quality uncertainty and the market mechanism. The Quarterly Journal of Economics, 90(4), 630-649. http://dx.doi.org/10.2307/1885326

Rullani, E. (1992). Economia delle risorse immateriali: Una introduzione. Sinergie, (29), 9-47.

Sahlman, W. A. (1990). The structure and governance of venture-capital organizations. Journal of Financial Economics, 27(2), 473-521. http://dx.doi.org/10.1016/0304-405x(90)90065-8

Sandri, S. (1994). La flessibilità nei modelli di finanza aziendale. Atti del Convegno AIDEA L'elasticità dell'azienda di fronte al cambiamento, in AA. VV., Clueb.

Schwienbacher, A., \& Larralde, B. (2010). Crowd funding of small entrepreneurial ventures. Handbook of Entrepreneurial Finance, Oxford University Press. Sciarelli, S. (2011). La gestione dell'impresa. Padova, Italia: Cedam.

Sohl, J., Van Osnabrugge, M., \& Robinson, R. (2000). Models of angel investing: Portals to the early stage market. In P. D. Reynolds, E. Autio, C. G. Brush, W. D. Bygrave, S. Manigart, H. J. Sapienza \& K.G. 
Shaver (Eds.), Frontiers of entrepreneurship research (p. 289). Babson Park, MA: Babson College.

Solomon, E. (1963). The theory of financial management. New York, NY: Columbia University Press.

Solomon, E. (1972). Teoria della finanza aziendale. Bologna, Italia: Il Mulino.

Sorrentino, M. (2003a). I business angel in Italia. In M. Mustilli, \& M. Sorrentino (Eds.), Business angel in Italia . Torino, Italia: Giappichelli.

Sorrentino, M. (2006). Venture capital informale e imprenditorialità innovativa. Sinergie, (71), 99-126.

Stiglitz, J., \& Weiss, A. (1981). Credit rationing in markets with imperfect information. American Economic Review, 71(3), 393-410.

Stinchcombe, A. L. (1965). Social structure and organizations. In J. March (Ed.), Handbook of organizations (pp. 142-193). Chicago, Randy McNally.

Sullivan, M. K., \& Miller, A. (1996). Segmenting the informal venture capital market: Economic, hedonistic, and altruistic investors. Journal of Business Research, 36(1), 25-35. http://dx.doi.org/10.1016/0148-2963(95)00160-3

Szego, B. (2002). Il venture capital come strumento per lo sviluppo delle PMI. Banca d'Italia, Quaderni di ricerca giuridica, n. 55, 1-82.

Tagliagambe, S., \& Usai, G. (1999). Organizzazioni. Milano, Italia: Giuffrè.

Trotta, A. (2001). Finanza innovativa per le piccole imprese. Le prospettive di sviluppo dell'Informal Venture Capital Market in Italia. Padova, Italia: Cedam.

Vicari, S. (1989). Invisible assets e comportamento incrementale. Finanza, Marketing e Produzione, (1), 63-86.

Vicari, S. (1995). Verso il resource-based management. In S. Vicari (Ed.), Brand equity. Il potenziale generativo della fiducia (pp. 9-48). Milano, Italia: Egea.

Von Bertalanffy, L. (1956). General system theory. In F. E. Emery (Ed.), General system, yearbook of the society for the advancement of general system theory (Vol. 1, pp. 1-10).

Von Bertalanffy, L. (1971). Teoria generale dei sistemi. Milano, Italia: ISEDI.

Wash, R., \& Solomon, J. (2011). Crowd funding and the return rule: Reducing risk but increasing spread. Communication Arts and Sciences, $X(\mathrm{X}), 18-20$. Working papers, Michigan State University.

Weston, J. F., \& Brigham, F. (1974). Finanza aziendale. Bologna, Italia: Il Mulino.

Weston, J. F., \& Brigham, F. (1978). Managerial finance (6th ed.). Dryden Press.

Wetzel, W. E. (1986). Informal risk capital: Knowns and unknonws. In D. L. Sexton \& R. W. Smilor (Eds.), The art and science of entrepreneurship (pp. 85-108). Ballenger Publishing Company, Cambridge, Massachusetts.

Winter, S. G. (1987). Knowledge and competence as strategic assets. In D. J. Teece (Ed.), The competitive challenge: Strategies for industrial innovation and renewal (pp. 159-184). Cambridge, MA: Ballinger.

Zappa, G. (1937). Il reddito d'impresa: scritture doppie, conti e bilanci di aziende commerciali. Milano, Italia: Giuffrè.

Zappa, G. (1956). Le produzioni nell'economia delle imprese. Milano, Italia: Giuffrè.

\section{Note}

Note 1. Schwienbacher \& Larralde (2010) describe the crowdfunding as "an open call, Essentially through the Internet, for the provision of financial resources either in the form of donation or in exchange for some form of reward and / or voting rights in order to support Initiatives for specific purposes".

\section{Copyrights}

Copyright for this article is retained by the author(s), with first publication rights granted to the journal.

This is an open-access article distributed under the terms and conditions of the Creative Commons Attribution license (http://creativecommons.org/licenses/by/3.0/). 